\title{
CORRECTION
}

\section{Correction to: Identification of an individual with a SYNGAP1 pathogenic mutation in India}

\author{
Vijaya Verma $^{1} \cdot$ Amit Mandora $^{2} \cdot$ Abhijeet Botre $^{3} \cdot$ James P. Clement $^{1}$
}

Published online: 24 August 2021

(c) Springer Nature B.V. 2021

\section{Correction to: \\ Molecular Biology Reports (2020) 47:9225-9234 \\ https://doi.org/10.1007/s11033-020-05915-4}

In the original publication of the article, the word SYNGAPI was incorrectly published. The correct spelling of the word $S Y N G A P 1$ is provided in this correction. The original article has been corrected.

Publisher's Note Springer Nature remains neutral with regard to jurisdictional claims in published maps and institutional affiliations.

The original article can be found online at https://doi.org/10.1007/ s11033-020-05915-4.

\section{James P. Clement}

clement@jncasr.ac.in

1 Neuroscience Unit, Jawaharlal Nehru Centre for Advanced Scientific Research, Bangalore 560064, India

2 SYNGAP1 Research Foundation, Pune, India

3 Paediatric Neurology and Epilepsy, KEM Hospital, Pune, India 